\title{
The management of xanthogranulomatous cholecystitis
}

Gürcan Şimşek(D), Alpaslan Şahin(D), Şükrü Hakan Metin(D), Mehmet Eşref Ulutaş(D), Kemal Arslan(D)

Clinic of General Surgery, University of Health Science Konya City Hospital, Konya, Turkey

\begin{abstract}
Objective: Xanthogranulomatous cholecystitis (XGC) is a rare variant of chronic cholecystitis. This rare pathology is characterized by severe and progressive fibrosis of the gallbladder wall as well as infiltration of fat-laden macrophages.

Material and Methods: The final pathology report of 8213 cholecystectomies performed between 2011 and 2019 was evaluated retrospectively, and patients whose pathology result was reported as XGC were included in the study. Patients' demographic characteristics, pathology results, and surgical methods were evaluated. Logistic regression analysis was performed for risk factors on conversion to open cholecystectomy.

Results: The rate of XGC among cholecystectomies was $0.91 \%$. Mean age of the patients was 57.32 years. Laparoscopic cholecystectomy was applied to $92 \%$ ( $n: 69$ ) of the patients. None of the patients had cancer suspicion in the preoperative period, but cancer suspicion was found in $10.6 \%$ of the patients during the operation. With the frozen test, unnecessary surgeries were prevented in these patients. Conversion rate to open cholecystectomy was found to be $26.09 \%$. The most common reason for conversion to open cholecystectomy (66.7\%) was intense fibrosis. Increased gallbladder wall thickness and acute cholecystitis were found to be statistically significant risk factors in ultrasonography $(p<0.05)$. Total complication rate in XGC cases was $3.9 \%$.
\end{abstract}

Conclusion: XGC is an extremely rare disease and is difficult to diagnose before cholecystectomy. Especially in preoperative USG, in cases with no suspicion of malignancy, but with suspected malignancy during the operation, histopathological examination with frozen method before extensive surgery may prevent unnecessary dissection and related morbidities.

Keywords: Cholecystitis, xanthogranulomatous, laparoscopic cholecystectomy

Cite this article as: Şimşek G, Şahin A, Metin ŞH, Ulutaş ME, Arslan K. The management of xanthogranulomatous cholecystitis. Turk J Surg 2021; 37 (3): 242-246.

\section{Corresponding Author}

Gürcan Şimşek

E-mail: gurcansimsek@gmail.com

Received: 27.11 .2020

Accepted: 19.04.2021

Available Online Date: 28.09 .2021

( Copyright 2021 by Turkish Surgical Society Available online at www.turkjsurg.com

DOI: $10.47717 /$ turkjsurg.2021.5020

\section{INTRODUCTION}

Xanthogranulomatous cholecystitis (XGC) is a rare variant of chronic cholecystitis (1). This rare inflammatory disease of the gallbladder is characterized by severe proliferation of the fibrotic tissue accompanied by the accumulation of lipid-laden macrophages and acute and chronic inflammatory cells $(2,3)$. XGC is a benign condition, but it often extends into neighboring organs, and its macroscopic appearance may be confused with gallbladder cancer $(4,5)$. Therefore, unnecessary major surgical procedures can be performed on patients with XCG (6).

XCG can present clinically with acute or chronic cholecystitis. Differential diagnosis between XGC and gallbladder cancer is often difficult, especially in patients with severe fibrosis $(4,5)$. Laparoscopic cholecystectomy (LC) is the gold standard in the treatment of benign gallbladder diseases. XGC has a high conversion rate from LC to open cholecystectomy $(\mathrm{OC})(7,8)$.

The aim of the present study was to reveal the general demographic and clinical characteristics of patients with XCG. Additionally, it was aimed to evaluate risk factors affecting conversion to $\mathrm{OC}$ and perioperative complications in patients with XCG.

\section{MATERIAL and METHODS}

In our study, we adhered to the World Medical Association's Helsinki Declaration regarding human material and data. In this study, the final pathology reports of cholecystectomies performed in our clinic between 2011 and 2019 were evaluated retrospectively. Our study was approved by the Research Ethics Committee of Health Sciences University, Hamidiye Scientific (Decision No: 2020-24/7). 


\section{Patients and Study Design}

Patients whose final pathology result was reported as XGC were included in the study. The parameters evaluated in the patients included in the study were as follows:

- Demographic characteristics

- Preoperative ultrasonography (USG) findings (gallstone and gallbladder wall thickness)

- Aspartate transaminase (AST), alanine transaminase (ALT), alkaline phosphatase (ALP), and gamma-glutamyl transferase (GGT) values.

- Anamnesis of acute pancreatitis or acute cholecystitis attack

- Indications for cholecystectomy and surgery type (OC or LC)

- The number of patients converting from LC to OC

- Reasons for conversion to OC.

- Perioperative complications and treatments.

- The management of patients with suspected malignancy in the preoperative period or during surgery.

- Presence of accompanying other malignancy.

Patient files, electronic hospital records, surgical book records, and polyclinic follow-up records of the patients were examined. Patients with missing data in their records were not included in the study. For conversion to OC; male sex; acute cholecystitis attack; biliary pancreatitis attack; increase in gallbladder wall thickness on USG; and AST, ALT, ALP, and GGT values higher than normal limits were evaluated as risk factors. These risk factors were evaluated using logistic regression analysis.

\section{Statistical Analysis}

SPSS for Windows, version 22 (IBM Corp, Armonk, NY) was used for statistical analysis, and $p<0.05$ was accepted as the statistical significance limit. Shapiro-Wilk normality test was applied before choosing the statistical method. If normality assumption could not be achieved in any of the groups, nonparametric test methods were preferred. Mann-Whitney $U$ test was applied to compare the variables obtained by the measurement. In terms of categorical variables, Chi-square and Fisher's exact test were used for differences and relationships between the groups.

Logistic regression analysis was performed to determine the risk factors considered to affect the transition to open cholecystectomy. The relevant odds, 95\% confidence interval, and $p$ values were presented. Comparative results were presented with median and average in quantitative variables and proportions in qualitative variables.

\section{RESULTS}

Of the 8213 cholecystectomy specimens evaluated in our study, 75 were detected to have XGC. The incidence of XGC was $0.91 \%$
Table 1. Demographic characteristics, preoperative USG findings and operation types of XGC patients

\begin{tabular}{|l|c|}
\hline \multicolumn{1}{|l|}{$\begin{array}{l}\text { Age } \\
\text { Average }\end{array}$} & $57.32 \pm 5.2$ \\
\hline \multicolumn{1}{|l|}{ Memale } & $52 \%(n=39)$ \\
\hline Preoperative USG gallstone & $48 \%(n=36)$ \\
Preoperative USG gallsludge & $73.3 \%(n=55)$ \\
\hline Preoperative USG gallbladder wall thickness increase & $26.7 \%(n=20)$ \\
\hline Lap. cholecystectomy & $32 \%(n=24)$ \\
\hline Open cholecystectomy & $92 \%(n=69)$ \\
\hline Conversion rate to open cholecystectomy & $8 \%(n=6)$ \\
\hline
\end{tabular}

Table 2. Indications for cholecystectomy in Xanthogranulomatous cholecystitis patients

\begin{tabular}{|l|c|}
\hline Chronic calculus cholecystitis & $50.7 \%(n=38)$ \\
\hline Acute calculus cholecystitis (same hospitalization) & $20 \%(n=15)$ \\
\hline Acute calculus cholecystitis attack & $14.7 \%(n=11)$ \\
\hline Acute pancreatitis attack & $10.7 \%(n=8)$ \\
\hline Common bile duct stone operation & $2.7 \%(n=2)$ \\
\hline Incidental operation & $1.3 \%(n=1)$ \\
\hline
\end{tabular}

among all cholecystectomies. Mean age of the patients was 57.32 years, and $48 \%$ were females (Table 1 ).

On preoperative USG, stones were reported in $73.3 \%$ of the patients and sludge in $26.7 \%$ of the patients. Only $32 \%$ of the patients had increased gallbladder wall thickness (Table 1).

Laparoscopic surgery was started in $92 \%$ of the patients, but $26 \%$ $(n=18)$ of these patients were converted to OC. Eight patients had an OC; two had common bile duct stones [Endoscopic retrograde cholangiopancreatography (ERCP) was performed but not successfully], and six patients had previous surgery. The most common indication for cholecystectomy in the patients was chronic stony cholecystitis (50.7\%) (Table 2).

The most common reason for conversion to $\mathrm{OC}$ was found to be severe fibrosis (66.7\%). Difficulty in dissecting Callot's triangle (5.5\%) and previous surgeries (27.8\%) were other reasons for conversion to OC.

Logistic regression analysis of the risk factors for conversion to OC revealed that increase in wall thickness increase and acute cholecystitis attack on USG were statistically significant risk factors ( $p<$ 0.05) (Table 3).

There was no suspicion of gallbladder cancer in USG performed in the preoperative period in any patient in the study. However, gallbladder cancer was suspected in eight patients (all of whom were patients who were converted to OC) during surgery. Biopsy 
Table 3. Logistic regression analysis results of risk factors associated with conversion to open cholecystectomy

\begin{tabular}{|l|c|c|}
\hline & OR [95\% C.I] & P \\
\hline Increase in gallbladder wall thickness on USG & $3.654[1.184-11.231]$ & 0.02 \\
\hline Male sex & $0.889[0.303-2.605]$ & 0.830 \\
\hline Acute cholecystitis attack & $4.800[1.519-15.164]$ & $\mathbf{0 . 0 0 5}$ \\
\hline Biliary pancreatitis attack & $0.941[0.092-9.671]$ & 0.959 \\
\hline Elevated AST level & $1.441[0.123-16.920]$ & 0.770 \\
\hline Elevated ALT level & $1.500[0.33-6.75]$ & 0.595 \\
\hline Elevated ALP level & $2.688[0.78-9.25]$ & 0.109 \\
\hline Elevated GGT level & $1.750[0.581-5.267]$ & 0.317 \\
\hline AST: Aspartate aminotransferase, ALT: Alanine transaminase, ALP: Alkaline phosphatase, GGT: Gamma-glutamyl transferase.
\end{tabular}

Table 4. Postoperative complication in XCG patients

\begin{tabular}{|l|l|}
\hline Postopoperative complication & $3.9 \%(n=3)$ \\
\hline Major bile duct injury & $1.3 \%(n=1)$ \\
Bilioma & $1.3 \%(n=1)$ \\
Surgical site infection & $1.3 \%(n=1)$ \\
\hline Re-operation & $1.3 \%(n=1)$ \\
\hline
\end{tabular}

was taken from all eight patients, and frozen sections were performed. Extensive surgery was not performed because the biopsy results were reported as benign. The final pathologic examination results of these eight patients' cholecystectomy materials were also reported as XCG. Concurrent gallbladder cancer was not detected in any patients included in our study.

Postoperative complications were found in three patients in our study. Surgical site infection was seen in the patient who was converted from laparoscopy to OC. Biliary injury and biloma were seen among patients who underwent LC. The biliary injury was Bismuth type 2 and was treated with Roux-en-Y hepaticojejunostomy. The patient with biloma was treated with wig drainage and an ERCP-stent (Table 4).

In our study, the rate of accompanying malignancy $(n=2)$ was found as $2.6 \%$. One patient had colon cancer and the other had stomach cancer.

\section{DISCUSSION}

The incidence of XGC has been reported as 0.9\% in 4773 cholecystectomies in St James's University Hospital, England. However, it has been reported in the literature that this rate is around $8 \%$, especially in studies from India (1). The rate of $0.91 \%$ detected in 8213 cholecystectomies in our study reflects that the frequency of XGC in our country is similar to Europe. The difference in the incidence of XGC between the sexes is quite low, and mean age of onset is 53.1 years (1). In our study, there was no significant difference in the sex distribution of the patients, and mean age was found as 57.32 years.
The most common preoperative symptom in patients with XGC is abdominal pain, and the most common examination finding is Murphy's sign (9-11). When the indications for cholecystectomy in patients with XCG were examined, the most common was chronic calculus cholecystitis (50.7\%). The frequency of acute calculus cholecystitis attack among patients with XGC was found as $34.6 \%(n=26)$. The frequency of acute pancreatitis attack was found as $10.7 \%(n=8)$. Some $10-15 \%$ of the adult population in Western societies has gallstones. The rate of acute cholecystitis in patients with gallstones is around 20\% (12). In view of these data, the rate of acute cholecystitis attack seems to be high in patients with XGC in our study. However, no study has demonstrated the relationship between XGC and acute cholecystitis. Although there is a very strong relationship between XGC and gallstones, not all patients with XGC will have stones. The relationship between XGC and gallstones has been reported as between $92 \%$ and $100 \%(1,10,13)$. In our study, the rate of stones on USG was found as $73.3 \%(n=55)$. However, bile sludge was detected using USG in all patients without gallstones.

In our study, no cancer suspicion was reported on preoperative USG in any patients. The incidence of gallbladder cancer associated with XGC has been determined as 3.3\% in Europe. In addition, approximately $10 \%$ of the patients with XGC had gallbladder cancer mixed with XGC, and patients received over or under treatment (1). None of the patients with XCG in our study had associated gallbladder cancer. However, in eight (10.6\%) patients, it was determined that there was a suspicion of cancer during surgery. A perioperative biopsy was performed in these patients. Biopsies were evaluated using frozen sections. Biopsy results were reported as benign in all cases. Only cholecystectomy was performed on these patients, and extensive surgery was avoided. Gallbladder cancer was not detected in the definitive pathology results in any of these patients. In cases with no suspicion of gallbladder cancer on preoperative USG imaging, the frozen section may prevent extensive surgical resections in 
the presence of perioperative cancer suspicion. There are no data on such an approach in the literature.

Laparoscopic cholecystectomy is the gold standard treatment for cholelithiasis worldwide. The conversion rate to $O C$ is between $1 \%$ and $15 \%$ (13). In our study, the rate of deficit conversion in patients with XGC was found as $26.09 \%(n=18)$. This rate is quite high compared with the literature. Reasons for conversion to $\mathrm{OC}$ include intense fibrosis and inflammation, inability to dissect Callot's triangle, ambiguous anatomy, life-threatening bleeding, and major bile duct injuries (14). In our study, the most common reason for conversion to $\mathrm{OC}$ in patients with XCG was severe fibrosis in $66.7 \%(n=12)$. Other reasons were difficulty in dissecting Callot's triangle $5.5 \%(n=1)$ and previous surgery $27.8 \%(n=5)$.

Many risk factors for conversion to $\mathrm{OC}$ have been evaluated in the literature (15). Obesity, increased gallbladder wall thickness, age over 65 years, presence of common bile duct stones, impacted stones in the neck of the gallbladder, previous upper abdominal surgery, male sex, high ALP levels, elevated total bilirubin levels, emergency surgery, high white blood cell (WBC) levels, and high ASA scores have been defined as risk factors for conversion to $\mathrm{OC}$ in the literature. However, it has been emphasized that scoring systems that include these factors rather than a single factor are more useful (9-11). In our study, we evaluated the risk factors for conversion to $O C$ in patients XGC using logistic regression analysis. We did not find a risk analysis for conversion to OC in XGC patients in the literature. Increased gallbladder wall thickness and acute cholecystitis attack in patients with XGC were statistically significant risk factors for conversion to OC (Table 3).

The frequency of major bile duct injury in LC is $0.2 \%$ (16). We found that the rate of major biliary injury due to LC was $1.3 \%$ in patients with XGC. This rate is high compared with major bile duct injury due to LC. However, there is no specified rate for major bile duct injury in patients with XCG in the literature.

\section{CONCLUSION}

XGC is a very rare disease, and it is difficult to diagnose before performing cholecystectomy. There is a strong relationship between XGC and gallstones. XGC increases the conversion rate from $L C$ to OC. Risk factors affecting conversion from $L C$ to OC in patients with XGC are increased gallbladder wall thickness and acute cholecystitis attack. In patients with no suspicion of gallbladder cancer on preoperative USG but with suspected perioperative gallbladder cancer, performing biopsy with frozen section may prevent overtreatment.

Ethics Committee Approval: Study approval obtained from SBU Hamidiye Scientific Research Ethics Committee (Date: 20.11.2020, Number: 20/445).
Author Contributions: Concept - G.Ş.; Design - G.Ş.; Materials - Ş.H.M., A.S..; Data Collection and/or Processing - M.E.U.; Analysis and/or Interpratation A.Ş.; Literature Review - G.Ş.; Writing Manuscript - G.Ş.; Critical Reviews - K.A.

Conflict of Interest: The authors have no conflicts of interest to declare.

Financial Disclosure: The authors declared that this study has received no financial support.

\section{REFERENCES}

1. Hale MD, Roberts KJ, Hodson J, Scott N. Xanthogranulomatous cholecystitis: a European and global perspective. HPB (Oxford) 2014; 16: 448-58. [CrossRef]

2. Goodman ZD, Ishak KG. Xanthogranulomatous cholecystitis. Am J Surg Pathol 1981; 5(7): 653-9. [CrossRef]

3. Guzman-Valdivia G. Xanthogranulomatous cholecystitis: 15 years' experience. World J Surg 2004; 28(3): 254-25. [CrossRef]

4. Duber C, Stokel S, Wagner PK, Muller J. Xanthogranulomatous cholecystitis mimicking carcinoma of the gallbladder: CT finding. J Comput Assist Tomogr 1984; 8(6): 1195-8. [CrossRef]

5. Deng YL, Cheng NS, Zhang SJ, Ma WJ, Shrestha A, Li F-Y. Xanthogranulomatous cholecystitis mimicking gallbladder carcinoma: an analysis of 42 case. World J Gastroenterol 2015 Nov 28; 21(44): 126539. [CrossRef]

6. Spinelli A, Schumacher G, Pascher A, Lopez-Hanninen E. Extended surgical resection for xanthogranulomatous cholecystitis mimicking advanced gallbladder carcinoma: A case report and review of literature. World J Gastroenterol 2006; 12: 2293-6. [CrossRef]

7. Yucel O, Uzun MA, Tilki M, Alkan S. Xanthogranulomatous Cholecystitis: analysis of 108 patients. Indian J Surg 2017; 79(6): 510-4. [CrossRef]

8. Qasaimeh GR, Matalqah I, Bakkar S, Omari AA, Qasaimeh M. Xanthogranulomatous Cholecystitis in the Laparoscopic Era Is Still a Challenging Disease. J Gastrointest Surg.2015;19:1036-42. [CrossRef]

9. Yang T, Zhang B, Zhang J. Surgical treatment of xanthogranulomatous cholecystitis: experience in 33 cases. Hepatobiliary Pancreat Dis Int 2007; 6: 504-8. [CrossRef]

10. Parra J, Acinas O, Bueno J. Xanthogranulomatous cholecystitis: clinical, sonographic, and CT findings in 26 patients. AJR Am J Roentgenol 2000; 147: 979-83. [CrossRef]

11. Uchiyama K, Ozawa S, Ueno. Xanthogranulomatous cholecystitis: theuse of preoperative CT findings to differentiate it from gallbladder carcinoma. J Hepatobiliary Pancreat Surg 2009; 16:333-8. [CrossRef]

12. Ansaloni L, Pisano M, Coccolini F. 2016 WSES guidelines on acute calculous cholecystitis.World J Emerg Surg 2016; 11:25. [CrossRef]

13. Hu AS, Menon R, Gunnarsson R, de Costa. Risk factors for conversion of laparoscopic cholecystectomy to open surgery - a systematic literature review of 30 studies. Am J Surg 2017; 214:920-30. [CrossRef]

14. Ercan M, Bostanci EB, Teke Z. Predictive factors for conversion to open surgery in patients undergoing elective laparoscopic cholecystectomy. J Laparo Endosc Adv Surg Tech 2010; 20: 427-34. [CrossRef]

15. Amin A, Haider MI, Aamir IS. Preoperative and operative risk factors for conversion of laparoscopic cholecystectomy to open cholecystectomy in Pakistan. Cureus 2019 Aug; 11 (8): e5446. [CrossRef]

16. Strasberg S, Hertl N, Soper N. An analysis of the problem of biliary injury during laparascopic cholecystectomy. J Am Coll Surg 1995; 180: 101-25. [CrossRef]

Peer-review: Externally peer-reviewed. 


\title{
ORIJINAL ÇALIŞMA-ÖZET
}

Turk J Surg 2021; 37 (3): 242-246

\section{Nadir bir kolesistit nedeni: ksantogranulamatöz kolesistit}

\author{
Gürcan Şimşek, Alpaslan Şahin, Şükrü Hakan Metin, Mehmet Eşref Ulutaş, Kemal Arslan
}

Sağlık Bilimleri Üniversitesi Konya Şehir Hastanesi, Genel Cerrahi Kliniği, Konya, Türkiye

\section{ÖZET}

Giriş ve Amaç: Ksantogranülomatöz kolesistit (KSGK) kronik kolesistitin nadir görülen bir varyantıdır. Bu nadir patoloji safra kesesi duvarında ciddi ve ilerleyici fibrozis yanında yağ yüklü makrofajların infiltrasyonu ile karakterizedir.

Gereç ve Yöntem: 2011-2019 yılları arasında yapılan 8213 kolesistektominin nihai patoloji raporu retrospektif olarak değerlendirildi ve patoloji sonucu KSGK olarak rapor edilen hastalar çalışmaya dahil edildi. Hastaların demografik özellikleri, patoloji sonuçları, ameliyat şekilleri değerlendirildi. Açık kolesistektomiye dönüşte risk faktörleri için lojistik regresyon analizi yapıldı.

Bulgular: Kolesistektomiler içinde KSGK oranı \%0,91'di. Hastaların ortalama yaşı 57,32'ydi. Hastaların \%92 (n: 69)'sine laparoskopik kolesistektomi uygulanmıştı.Hiçbir hastada preoperatif dönemde kanser şüphesi yoktu ancak operasyonda kanser şüphesi hastaların \%10,6'sında bulundu. Frozen tetkiki ile bu hastalarda gereksiz cerrahilerin önüne geçildi. Açık kolesistektomiye dönme oranı $\% 26,09$ olarak bulundu. Açık kolesistektomiye en sık dönme nedeni $(\% 66,7)$ yoğun fibrozisti. Açık kolesistektomiye dönme için irdelenen risk faktörlerinden ultrasonografide safra kesesi duvar kalınlığı artışı ve akut kolesistit geçirmek istatiksel olarak anlamlı risk faktörü olarak bulundu $(p<0,05)$. KSGK vakalarında toplam komplikasyon oranı $\% 3,9^{\prime} \mathrm{du}$.

Sonuç: KSGK oldukça nadir bir hastalık olup kolesistektomi öncesi tanı koymak güçtür. Özellikle preoperatif yapılan ultrasonografide malignite şüphesi olmayan ancak operasyonda malignite kuşkulu vakalarda ekstansif cerrahi öncesi frozen yöntemi ile histopatolojik inceleme yapmak gereksiz diseksiyonu ve buna bağlı morbiditeleri engelleyebilir.

Anahtar Kelimeler: Kolesistit, ksantogranülomatöz, laparoskopik koleistektomi

Doi: $10.47717 /$ turkjsurg.2021.5020 